\title{
Follicular dynamics and dominance in Booroola $\times$ Finnish Landrace and Booroola $\times$ Suffolk ewes heterozygous for the $F$ gene
}

\author{
F. Castonguay*, J. J. Dufour, F. Minvielle $\dagger$ and R. Estrada \\ Département de zootechnie, Université Laval, Québec, Canada GIK 7 P4
}

\begin{abstract}
Summary. To study the influence of the $F$ gene on follicular dynamics and dominance, 2-year-old Booroola $\times$ Finnish Landrace $(B F L, N=17)$ and Booroola $\times$ Suffolk (BS, $N=18$ ) ewes were compared with contemporary purebred Finn (FL, $N=18$ ) and Suffolk $(S, N=18)$ ewes. In Exp. 1, oestrous cycles of ewes were synchronized during the breeding season with progestagen-impregnated sponges. At sponge removal (Day 0), 14 days after insertion, ewes of each of the 4 genetic groups were assigned to Group 1 in which all follicles visible on both ovaries were destroyed by electrocauterization except for the largest (F1) which was marked, Group 2 in which all visible follicles on both ovaries were destroyed, or Group 3 in which the 3 largest follicles of both ovaries were identified as F1, F2 and F3 and marked. At $48 \mathrm{~h}$ after treatment (Day 2), follicular growth was evaluated. At Day 0, the mean number of small follicles (1-3 mm) was higher $(P<0.05)$ for BS, S and BFL $(35.8,35.1$ and 32.9$)$ than FL (24.9) ewes. Large follicles $(\geq 4 \mathrm{~mm})$ were more numerous $(P<0.05)$ in FL $(3.5)$ than in BS $(2 \cdot 1)$ ewes, BFL and $\mathrm{S}$ ewes being intermediate. Diameter of the $\mathrm{F} 1$ follicle was larger $(P<0.05)$ for $\mathrm{S}(7.6 \mathrm{~mm})$ than FL, BS and BFL $(5.8,5.1$ and $5.1 \mathrm{~mm})$ ewes. In Group 1, all F1 follicles marked at Day 0 ovulated at oestrus after sponge removal for BFL, BS and S ewes while in FL ewes, 2 of $6 \mathrm{Fl}$ follicles regressed. In ewes ovulating, only the $\mathrm{F} 1$ follicle ovulated except for one $\mathrm{S}$ ewe which shed one more ovum. In Group 2, there were no follicles $\geq 4 \mathrm{~mm}$ at Day 2 and no ewes ovulated after treatment. In Group 3, the proportion of marked follicles that ovulated was higher for $S$ ewes than in those of the prolific genotypes. The number of follicles not marked at Day 0 but ovulating (compared to the total number of ovulations) was higher in BFL, BS and FL (8/11, 9/13 and 9/13) than S (3/10) ewes. In Exp. 2, prolific (BFL + BS) and non-prolific (S) ewes were compared following destruction of follicles $\geq 3 \mathrm{~mm}$ with the F1 left intact (Treatment 1) or destroyed (Treatment 2), 12 days after sponge insertion. At 4 days after treatment (at sponge removal), the numbers of 3-4 $\mathrm{mm}$ follicles were not different between the 2 treatments and a very high proportion of the F1 follicles left intact at Day 0 had regressed at Day 4 in both genotypes. From these results, it can be concluded that the higher ovulation rate in Booroola-crossed ewes is not associated with a higher number of recruitable follicles but involves late follicular-phase recruitment and selection combined with smaller preovulatory follicle diameters. Dominance by the largest follicle is not present in ewes of prolific or non-prolific genotypes. In contrast, it is likely that small sized follicles exert a negative effect on growth of large follicles.
\end{abstract}

Keywords: ewes; Booroola; atresia; follicle; dominance

\footnotetext{
*Present address: Ferme expérimentale La Pocatière, Agriculture Canada, C.P. 400, La Pocatière, Québec, Canada G0R 1 Z0.

†Present address: INRA-CNRZ, Laboratoire de Génétique Factorielle, 78350 Jouy en Josas, France.
} 


\title{
Introduction
}

Follicular growth leading to ovulation is controlled by complex mechanisms which include both extraovarian and intraovarian regulators. Pituitary gonadotrophins (FSH and $\mathrm{LH}$ ) are essential to allow development of follicles larger than $2 \mathrm{~mm}$ (Dufour et al., 1979; McNeilly et al., 1986), but the terminal development of large follicles is most probably regulated by local intraovarian factors rather than systemic hormonal concentrations (Cahill et al., 1985; Dorrington et al., 1987; Driancourt \& Fry, 1988; Fry et al., 1988). Numerous compounds have been identified in the follicular fluid and reported to stimulate (TGF: Ying et al., 1986; IGF : Dorrington et al., 1987) or inhibit (EGF: Shaw et al., 1985; inhibin: Ying et al., 1986; FRP: diZerega et al., 1987) follicular differentiation. These factors are most probably involved in the recruitment process that determines a group of follicles capable of ovulating and/or in the selection process during which a follicle is chosen to ovulate. However, the different patterns by which prolific breeds of sheep could achieve higher ovulation rates (Driancourt et al., 1986) highlight the complexity of terminal follicular growth. Romanov ewes have a large number of follicles recruited and a rate of follicular loss through atresia similar to Ile-de-France (non-prolific control) ewes, whereas Finn ewes have similar numbers of recruitable follicles but reduced atresia compared to Finn $\times$ Blackface ewes of lower prolificacy (Driancourt et al., 1986). In Booroola ewes, higher ovulation rate is reached by continuous recruitment during the follicular phase, a reduced amount of atresia and the ability of mature follicles to wait for ovulation (Driancourt et al., 1985a). In Booroola $\times$ Romanov crossbred ewes, Driancourt et al. (1986) observed that the model describing terminal follicular growth included features of both parental breeds.

Several models used to explain the pattern of follicular selection postulate that the largest follicle negatively influences follicular growth of smaller follicles. The inhibitory effect of the largest follicle is referred to as dominance, but although dominance has been demonstrated in women (Hodgen, 1982; Baird, 1987), monkeys (diZerega \& Hodgen, 1980) and cattle (Matton et al., 1981; Staigmiller \& England, 1982), no convincing data have been reported for sheep and the concept of dominance in these animals remains hypothetical (Bhérer et al., 1976; Driancourt, 1987). In the present study, selective cauterization of follicles of different size classes combined with ink-marking of large follicles was used to study the interactions between follicles of different size classes.

The objectives of this study were (1) to compare the follicular dynamics of Booroola $\times$ Finnish Landrace and Booroola $\times$ Suffolk ewes, heterozygous for the $F$ gene, with those of another prolific breed (purebred Finn) and a non-prolific breed (Suffolk) and (2) to evaluate and compare a possible effect of dominance of the largest follicle in prolific and non-prolific groups.

\section{Materials and Methods}

\begin{abstract}
Animals. Crossbred ewes heterozygous for the F gene were obtained from purebred Finnish Landrace and Suffolk ewes sired by Booroola rams (homozygous FF). Contemporary purebreds of the two maternal breeds were also produced. All progeny were housed at the experimental station of Laval University in St-Augustin. Ovulation rates of ewe lambs for their first 3 oestrous periods were recorded previously and the values obtained confirmed the $\mathrm{F}+$ genotype of crossed ewe lambs (Castonguay et al., 1990). Before treating the ewes in the present experiments, ovulation rate at first oestrus in the second breeding season was recorded by laparoscopy performed 5-8 days after onset of oestrus.
\end{abstract}

Experiment 1. At the beginning of the breeding season (October), oestrous cycles of 17 Booroola $\times$ Finnish Landrace (BFL), 18 Booroola $\times$ Suffolk (BS), 18 Finnish Landrace (FL) and 18 Suffolk (S) mature (2 years old) ewes were synchronized with vaginal sponges impregnated with medroxyprogesterone (Veramix; Upjohn, Canada). At sponge withdrawal (Day 0), 14 days after insertion, each ewe of the 4 genetic groups was laparotomized and assigned to one of 3 groups: Group 1, destruction by electrocauterization of all follicles visible (around $>0.5 \mathrm{~mm}$ ) on both ovaries, except the largest one of the 2 ovaries (identified as F1) which was marked; Group 2, destruction of all visible follicles on both ovaries; Group 3, marking of the 3 largest follicles of both ovaries, identified as F1, F2 and F3 respectively. At $48 \mathrm{~h}$ after treatment (Day 2), a second laparotomy was performed to measure previously marked 
follicles and evaluate follicular population. Detection of oestrus was started on Day 1 with vasectomized rams, three times daily $(07: 30,15: 00$ and 22:00 h). Interval to onset of oestrus was assumed to be the time between observation of oestrous behaviour and previous detection. A laparoscopy was done about 5 days after the beginning of oestrus to determine which follicles had ovulated and to count the total number of ovulations. Another laparoscopy was performed at the next oestrus for ewes that had not ovulated at oestrus after sponge removal.

Follicle marking was done by dots of India ink injected into the stroma surrounding the follicle, according to the technique of Dufour et al. (1972). Laparotomy was performed under general anaesthesia induced by xylazine (Rompun; Hoechst, Canada). At laparotomy, macroscopic follicular population was recorded and diameters of the $F 1, F 2$ and $F 3$ were measured with digital calipers. The position of marked follicles was also noted. Follicles were assigned to one of three diameter classes: small ( $(-3 \mathrm{~mm})$, medium $(3-4 \mathrm{~mm})$ and large $(\geq 4 \mathrm{~mm})$. A growing follicle was defined as a follicle which had a mean increment between two measures of at least $0.4 \mathrm{~mm}$. Results on follicular population are presented per pair of ovaries.

Experiment 2. The results of Exp. 1 did not show any differences between BFL and BS ewes in follicular population or follicular kinetics, and so it was decided to form a single group with the two genotypes (called B-crossed) to study the dominance effect. In the late breeding season (mid-January), the oestrous cycies of 17 B-crossed (9 BFL and 8 BS) and $18 \mathrm{~S}$ ewes were synchronized with vaginal sponges. Twelve (12) $\mathrm{S}$ ewes had not been used before and most of the other ewes ( 5 out of 6 for $S$ and 9 out of 17 for B-crossed) were from Group 3 (no follicles destroyed) of the Exp. 1. Moreover, all ewes had had at least 3 oestrous cycles (about 51 days) between Exps 1 and 2 to restore the natural follicular population.

At 12 days after sponge insertion (Day 0 ) ewes were laparotomized and assigned to one of the 3 following treatments: Treatment I, destruction of all follicles $\geq 3 \mathrm{~mm}$ visible on the ovarian surface except the largest (F1) which was ink-marked; Treatment 2 , destruction of all visible follicles $\geq 3 \mathrm{~mm}$; Treatment 3 , marking of the 3 largest follicles (F1, F2 and F3). At 4 days after treatment (Day 4), follicular growth was evaluated by a second laparotomy and sponges were removed. Detection for oestrus was carried out 3 times daily $(07: 30,15: 00$ and 22:00 h) beginning on Day 5. A laparoscopy was done 6 days after detection of oestrus to identify the ovulatory follicles and the total number of ovulations.

At laparotomy, the macroscopic follicular population was recorded and diameters of the F1, F2 and F3 follicles were measured as in Exp. 1. Data on follicular population are expressed per pair of ovaries.

Statistical analysis. One-way analysis of variance was carried out by using the general linear model procedure (SAS Institute, 1985), with genetic group as fixed effect. Proportions were analysed by using the $\chi^{2}$ test. Homogeneity of variances was tested, and no transformation was found to be necessary.

In Exp. 2, differences in number of follicles between Days 0 and 4 (for Treatments 1 and 2) were analysed by $t$ test to determine whether the increment differed from 0. Two-way ANOVA with treatment (Treatments 1 and 2) and genetic group as the fixed effects were carried out to analyse follicular population at Day 4 , onset of oestrus and ovulation rate.

\section{Results}

Ovulation rates at first oestrus of the breeding season were respectively $3 \cdot 7,3 \cdot 4,3 \cdot 1$ and $1 \cdot 8$ for BFL, BS, FL and S ewes (data not shown).

\section{Experiment 1}

Table 1 presents results on follicular population per pair of ovaries at first laparotomy (Day 0 ) before treatment. Mean number of large follicles $(\geq 4 \mathrm{~mm})$ was higher $(P<0.02)$ in FL purebred than in BFL, $\mathrm{S}$ and BS ewes. No differences were observed in mean number of medium sized follicles (3-4 mm) between genetic groups. Small follicles $(1-3 \mathrm{~mm})$ were more numerous $(P<0.03)$ in BS, $\mathrm{S}$ and BFL than in FL ewes. Diameter of the largest follicle $(\mathrm{F} 1)$ in $\mathrm{S}$ ewes was significantly larger $(P<0.001)$ than the values in FL, BFL and BS ewes. The second largest follicle (F2) was also larger $(P<0.05)$ in $\mathrm{S}$ compared to BS and BFL ewes, with FL ewes being intermediate.

In Group 1, in which all visible follicles except the F1 were destroyed, the mean number of follicles was low in the $3-4 \mathrm{~mm}$ and $1-3 \mathrm{~mm}$ classes, 2 days after treatment (Table 2). Diameters of the F1 follicle at Days 0 and 2 were larger (Table $3, P<0.01$ ) in S ewes than in FL, BFL and BS ewes. Onset of oestrus after sponge withdrawal (Table 3) was earlier $(P<0.02)$ in FL and S ewes than in BS ewes, with BFL ewes being intermediate. Almost all F1 follicles marked at Day 0 grew and ovulated in BFL, BS and S ewes, except for one follicle in an S ewe and one in a BS ewe which stayed at a steady size between Days 0 and 2 but ovulated nevertheless. In FL ewes, 2 F1 follicles 
Table 1. Follicular population and diameter of first (F1) and second (F2) largest follicle at sponge withdrawal (Day 0) in the 4 genetic groups (Exp. 1)

\begin{tabular}{|c|c|c|c|c|c|c|}
\hline \multirow{2}{*}{$\begin{array}{l}\text { Genetic } \\
\text { group }\end{array}$} & \multirow[b]{2}{*}{ No. } & \multicolumn{3}{|c|}{ No. of follicles at Day 0} & \multicolumn{2}{|c|}{ Diam. (mm) of follicle } \\
\hline & & $\geq 4 \mathrm{~mm}$ & $3-4 \mathrm{~mm}$ & $1-3 \mathrm{~mm}$ & F1 & F2 \\
\hline BFL & 17 & $2 \cdot 6 \pm 0.4^{b}$ & $2.9 \pm 0.6$ & $32 \cdot 9 \pm 3 \cdot 1^{\mathrm{a}}$ & $5 \cdot 1 \pm 0 \cdot 3^{b}$ & $4 \cdot 6 \pm 0.3^{b}$ \\
\hline BS & 18 & $2 \cdot 1 \pm 0.3^{b}$ & $2 \cdot 4 \pm 0 \cdot 3$ & $35 \cdot 8 \pm 3 \cdot 1^{\mathrm{a}}$ & $5 \cdot 1 \pm 0 \cdot 3^{b}$ & $4 \cdot 8 \pm 0 \cdot 3^{b}$ \\
\hline FL & 18 & $3 \cdot 5 \pm 0 \cdot 3^{\mathrm{a}}$ & $2 \cdot 6 \pm 0 \cdot 4$ & $24 \cdot 9 \pm 2 \cdot 2^{b}$ & $5.8 \pm 0.3^{b}$ & $5 \cdot 0 \pm 0 \cdot 3^{\mathrm{ab}}$ \\
\hline$s$ & 18 & $2 \cdot 4 \pm 0 \cdot 2^{b}$ & $1.8 \pm 0.5$ & $35 \cdot 1 \pm 2 \cdot 7^{\mathrm{a}}$ & $7 \cdot 6 \pm 0 \cdot 3^{a}$ & $5 \cdot 8 \pm 0 \cdot 4^{a}$ \\
\hline
\end{tabular}

Values are mean \pm standard error.

${ }^{\mathrm{a}, \mathrm{b}}$ Means in the same column with different letters differ significantly $(P<0.05)$.

did not ovulate, one stayed the same size between Days 0 and 2 and another grew to $9.6 \mathrm{~mm}$ but did not ovulate. In ovulating ewes, only the Fl follicle ovulated except for one $\mathrm{S}$ ewe which shed also one more ovum besides the $\mathrm{F} 1$ follicle. The mean diameter increment per day of the growing $\mathrm{F} 1$ follicles was $1.7,1.2,1.2$ and $0.9 \mathrm{~mm}$ for $\mathrm{S}, \mathrm{BS}, \mathrm{FL}$ and BFL ewes respectively (data not shown).

Table 2. Follicular population at Day 2 in ewes in Groups 1, 2 and 3 (Exp. 1)

\begin{tabular}{lccccc}
\hline & & \multicolumn{4}{c}{ No. of follicles at Day 2} \\
Group & $\begin{array}{c}\text { Genetic } \\
\text { group }\end{array}$ & No. & $\geq 4 \mathrm{~mm}$ & $3-4 \mathrm{~mm}$ & $1-3 \mathrm{~mm}$ \\
\hline 1 & BFL & 6 & $1 \cdot 0 \pm 0 \cdot 0$ & $0 \cdot 5 \pm 0 \cdot 5$ & $7 \cdot 5 \pm 2 \cdot 1$ \\
& BS & 6 & $1 \cdot 0 \pm 0 \cdot 0$ & $0 \cdot 3 \pm 0 \cdot 2$ & $8 \cdot 5 \pm 1 \cdot 6$ \\
& FL & 6 & $1 \cdot 0 \pm 0 \cdot 0$ & $0 \cdot 2 \pm 0 \cdot 2$ & $8 \cdot 2 \pm 1 \cdot 5$ \\
& S & 6 & $1 \cdot 0 \pm 0 \cdot 0$ & $0 \cdot 7 \pm 0 \cdot 3$ & $8 \cdot 7 \pm 0 \cdot 8$ \\
2 & BFL & 6 & $0 \cdot 0 \pm 0 \cdot 0$ & $0 \cdot 2 \pm 0 \cdot 2$ & $7 \cdot 3 \pm 2 \cdot 2$ \\
& BS & 6 & $0 \cdot 0 \pm 0 \cdot 0$ & $0 \cdot 7 \pm 0 \cdot 3$ & $9 \cdot 0 \pm 2 \cdot 2$ \\
& FL & 6 & $0 \cdot 0 \pm 0 \cdot 0$ & $0 \cdot 0 \pm 0 \cdot 0$ & $5 \cdot 2 \pm 1 \cdot 1$ \\
& S & 6 & $0 \cdot 0 \pm 0 \cdot 0$ & $0 \cdot 0 \pm 0 \cdot 0$ & $9 \cdot 7 \pm 1 \cdot 3$ \\
3 & BFL & 5 & $3 \cdot 8 \pm 0 \cdot 6^{\text {ab }}$ & $2 \cdot 8 \pm 0 \cdot 4$ & $30 \cdot 4 \pm 3 \cdot 0^{\text {ab }}$ \\
& BS & 6 & $3 \cdot 7 \pm 0 \cdot 3^{\text {ab }}$ & $2 \cdot 2 \pm 0 \cdot 6$ & $24 \cdot 3 \pm 4 \cdot 0^{\mathrm{b}}$ \\
& FL & 6 & $4 \cdot 8 \pm 0 \cdot 4^{\mathrm{a}}$ & $1 \cdot 3 \pm 0 \cdot 6$ & $23 \cdot 2 \pm 2 \cdot 1^{\mathrm{b}}$ \\
& S & 6 & $3.0 \pm 0 \cdot 3^{\mathrm{b}}$ & $1 \cdot 5 \pm 0 \cdot 8$ & $34 \cdot 7 \pm 1 \cdot 6^{\mathrm{a}}$ \\
\hline
\end{tabular}

Values are mean \pm standard error.

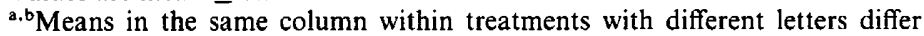
significantly $(P<0.05)$.

At 2 days after destruction of all visible follicles (Group 2), no large follicle ( $\geq 4 \mathrm{~mm}$ ) was observed in the 4 genetic groups and only a few follicles of smaller size classes were present (Table 2). All ewes exhibited oestrus after surgery but no ovulations were observed (data not shown). Ewes ovulated only at the second oestrus which occurred 17.2, 16.8, 16.4 and 15.1 days after Day 0 respectively for BFL, S, BS and FL ewes with a standard deviation of about 2 days. Corresponding ovulation rates were $3.5,2.0,1.8$ and 1.8 (BFL vs others, $P<0.03$ ).

In the control group (Group 3) in which the 3 largest follicles at Day 0 were marked, FL ewes had more follicles $\geq 4 \mathrm{~mm}, 2$ days after treatment, than did $S$ ewes, Booroola crosses being intermediate (Table 2). A similar proportion of follicles marked at Day 0 (F1, F2 and F3) grew between Days 0 and 2 in the four genotypes (Table 4). The increment in diameter for growing follicles was not statistically different between genotypes. The number of ovulatory F1 follicles (compared to 
Table 3. Follicular kinetics of the first largest follicle (F1) between Days 0 and 2 after destruction at sponge withdrawal (Day 0) of all visible follicles except the F1 (Group 1,

Exp. 1)

\begin{tabular}{|c|c|c|c|c|c|c|}
\hline \multirow{2}{*}{$\begin{array}{l}\text { Genetic } \\
\text { group }\end{array}$} & \multirow[b]{2}{*}{ No. } & \multicolumn{2}{|c|}{ Diam. of the $F 1$ follicle (mm) } & \multirow{2}{*}{$\begin{array}{l}\% \text { of } F 1 \text { follicles } \\
\text { marked at Day } 0 \\
\text { and ovulating }\end{array}$} & \multirow{2}{*}{$\begin{array}{l}\text { Onset of } \\
\text { oestrus (h) }\end{array}$} & \multirow{2}{*}{$\begin{array}{l}\text { Ovulation } \\
\text { rate }\end{array}$} \\
\hline & & At Day 0 & At Day 2 & & & \\
\hline BFL & 6 & $5 \cdot 1 \pm 0.7^{b}$ & $6 \cdot 9 \pm 0 \cdot 6^{b}$ & $100 \cdot 0$ & $50 \cdot 6 \pm 6 \cdot 3^{\mathrm{ab}}$ & $1 \cdot 0 \pm 0 \cdot 0$ \\
\hline BS & 6 & $4.9 \pm 0.4^{b}$ & $6.9 \pm 0 \cdot 4^{b}$ & $100 \cdot 0$ & $60 \cdot 3 \pm 6 \cdot 6^{a}$ & $1 \cdot 0 \pm 0 \cdot 0$ \\
\hline FL & 6 & $5.9 \pm 0.3^{b}$ & $7 \cdot 8 \pm 0 \cdot 8^{b}$ & $66 \cdot 7$ & $36 \cdot 6 \pm 3 \cdot 7^{b}$ & $1 \cdot 0 \pm 0 \cdot 0$ \\
\hline$S$ & 6 & $7 \cdot 6 \pm 0.7^{a}$ & $10 \cdot 4 \pm 0 \cdot 8^{\mathrm{a}}$ & $100 \cdot 0$ & $37 \cdot 7 \pm 4 \cdot 9^{b}$ & $1 \cdot 2 \pm 0 \cdot 2$ \\
\hline
\end{tabular}

Values are mean \pm standard error.

a, Means in the same column with different letters differ significantly $(P<0.05)$.

those marked at Day 0) was relatively high (Table 4) in S ewes and was lower in other genetic groups. Of the F2 follicles marked at Day 0, 50\% ovulated in BFL, FL and S ewes compared with $0 \%$ in BS ewes $(P<0.20)$, while the only $\mathrm{F} 3$ follicles that reached ovulation were in BS ewes $(P<0 \cdot 12)$. The proportion of $\mathrm{F} 1$ and $\mathrm{F} 2$ follicles that ovulated tended $(P<0 \cdot 20)$ to be slightly higher in $\mathrm{S}$ ewes. All ovulatory follicles marked at Day 0 had increased in size by Day 2 except for one F2 follicle in a BFL ewe which slightly regressed $(-0.5 \mathrm{~mm})$. The number of follicles not marked at Day 0 but that ovulated (compared to the total number of ovulations) was relatively higher in BFL, BS and FL than in S ewes but the differences were not significant (Table 4). Mean diameters at Day 0 of all marked follicles that eventually ovulated (data not shown) were $7 \cdot 2,5 \cdot 6$, 5.3 and $4.8 \mathrm{~mm}$ in S, FL, BFL and BS ewes respectively but, since relatively high numbers of ovulations were from unmeasured follicles at Day 0 (8, 9, 9 and 3 for BFL, BS, FL and S; Table 4) and were probably smaller than $4 \mathrm{~mm}$ at Day 0 , these diameters are certainly overestimated, mostly in prolific genotypes. The diameter at Day 2 of follicles that ovulated was higher in $\mathrm{S}(8.7 \mathrm{~mm}$, $P<0.001)$ than in FL, BS and BFL $(6.4,5.7$ and $5.1 \mathrm{~mm})$ ewes, but 3 ovulatory follicles in BFL ewes were not measured at Day 2 compared to only one in the other genotypes. In prolific groups, diameter at Day 2 of ovulatory follicles was higher in ewes shedding two ova compared to those shedding more than $2(6.3 \pm 1 \cdot 0,6.6 \pm 0.5$ and $5.2 \pm 0.3 \mathrm{~mm}$ for ewes with 1,2 and $\geq 3$ ovulations, $P<0.05$ ). The onset of oestrus after sponge withdrawal was not different between genotypes. The ovulation rates did not differ significantly.

\section{Experiment 2}

In ewes of Treatment 1 (Table 5) in which all follicles $\geq 3 \mathrm{~mm}$ except the $\mathrm{F} 1$ follicle were destroyed, the mean diameter of the Fl follicle at Day 0 tended to be higher in $\mathrm{S}$ ewes $(P<0 \cdot 08)$. At 4 days after treatment, the mean number of $3-4 \mathrm{~mm}$ follicles increased significantly $(P<0 \cdot 64)$ in the two groups and was not different between groups. $S$ ewes had more follicles $\geq 4 \mathrm{~mm}$ than did B-crossed ewes at Day $4(P<0.02)$ and the increment between Days 0 and 4 was significant in both genotypes $(P<0 \cdot 02)$. Proportions of F1 follicles left at Day 0 and growing between Days 0 and 4 were small for both groups and their mean diameters at Day 4 were similar. The only F1 follicle that ovulated was in a B-crossed ewe. Diameter of the F2 follicles at Day 4 was higher in $\mathrm{S}$ ewes $(P<0.03)$ and the same tendency was noted for $\mathrm{F} 3$ follicles $(P<0.06)$. Time to oestrus after sponge withdrawal was not different between groups. All ewes ovulated and ovulation rate did not differ.

In Treatment 2 in which all follicles $\geq 3 \mathrm{~mm}$ were cauterized at Day 0 , the number of follicles $\geq 3 \mathrm{~mm}$ increased significantly $(P<0.03)$ between Days 0 and 4 in both groups but did not differ between genotypes at Day 4 (Table 5). The diameter of the F1 follicle at Day 4 was higher in $\mathrm{S}$ ewes

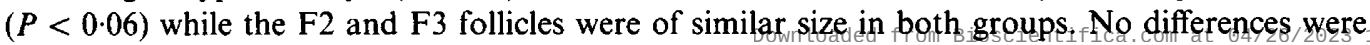




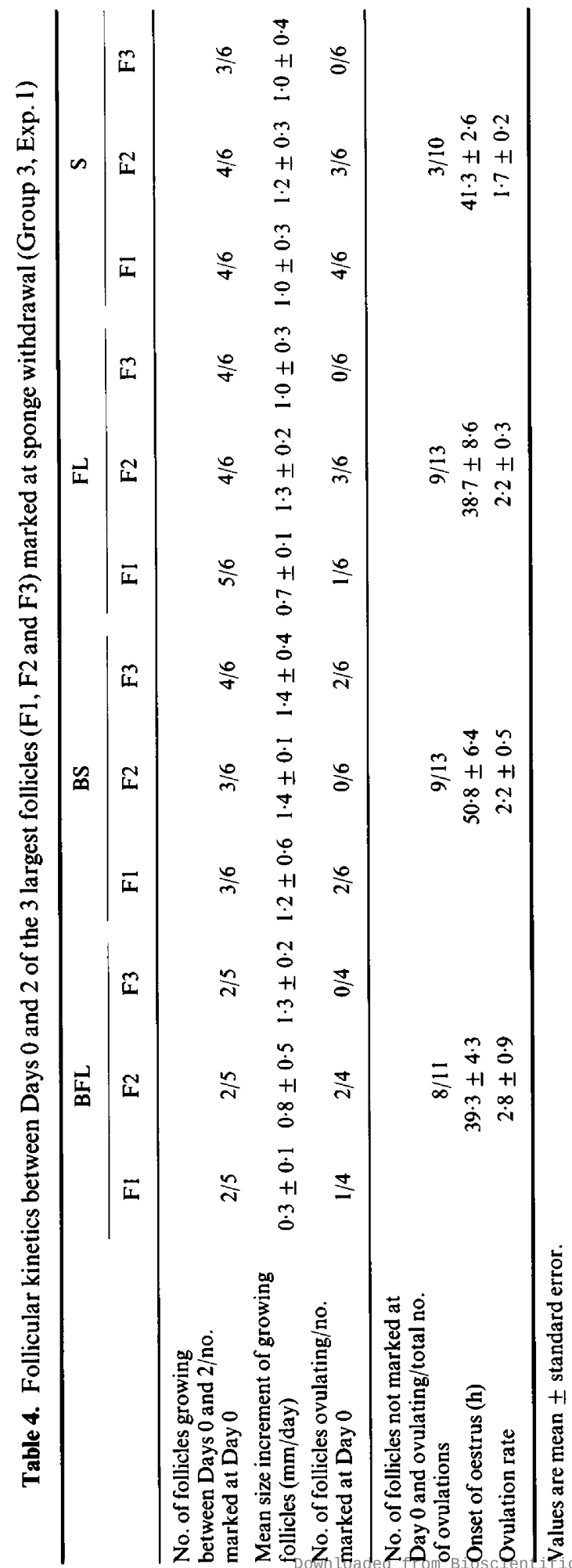


Table 5. Follicular kinetics between Days 0 and 4 after destruction at Day 0 of all follicles $\geq 3 \mathrm{~mm}$ in diameter including or not the largest follicle (F1) in Booroola-crossed or Suffolk ewes (Treatments 1 and 2, Exp. 2)

\begin{tabular}{|c|c|c|c|c|}
\hline & \multicolumn{2}{|c|}{$\begin{array}{l}\text { Treatment } 1 \\
\text { (F1 intact) }\end{array}$} & \multicolumn{2}{|c|}{$\begin{array}{l}\text { Treatment } 2 \\
\text { (F1 destroyed) }\end{array}$} \\
\hline & B-crossed & Suffolk & B-crossed & Suffolk \\
\hline Diameter of $F 1$ at Day $0(\mathrm{~mm})$ & $3 \cdot 9 \pm 0 \cdot 2(6)$ & $5 \cdot 6 \pm 0 \cdot 8(6)$ & - & - \\
\hline No. of follicles $34 \mathrm{~mm}$ at Day 4 & $1 \cdot 7 \pm 0.6$ & $2 \cdot 3 \pm 0 \cdot 7$ & $1 \cdot 2 \pm 0 \cdot 2(5)$ & $2 \cdot 2 \pm 0 \cdot 8(6)$ \\
\hline No. of follicles $\geq 4 \mathrm{~mm}$ at Day 4 & $0.5 \pm 0.2^{b}$ & $2 \cdot 5 \pm 0 \cdot 7^{a}$ & $1 \cdot 0 \pm 0.3$ & $1 \cdot 3 \pm 0 \cdot 2$ \\
\hline Diameter of $\mathrm{F} 1$ at Day $4(\mathrm{~mm})$ & $4 \cdot 4 \pm 0 \cdot 0$ & $6.7 \pm 0.6$ & $4 \cdot 4 \pm 0.2$ & $5.9 \pm 0.6$ \\
\hline Diameter of F2 at Day $4(\mathrm{~mm})$ & $3 \cdot 8 \pm 0 \cdot 4^{b}$ & $5 \cdot 5 \pm 0 \cdot 5^{a}$ & $3.5 \pm 0.2$ & $3.9 \pm 0.4$ \\
\hline Diameter of F3 at Day $4(\mathrm{~mm})$ & $3 \cdot 0 \pm 0 \cdot 1$ & $4 \cdot 1 \pm 0 \cdot 5$ & $2 \cdot 8 \pm 0.2$ & $3 \cdot 1 \pm 0 \cdot 2$ \\
\hline $\begin{array}{l}\text { Proportion of } F 1 \text { marked at Day } 0 \text { and } \\
\text { growing between Days } 0 \text { and } 4(\%)\end{array}$ & $16 \cdot 7$ & $33 \cdot 3$ & - & - \\
\hline $\begin{array}{l}\text { Proportion of Fl marked at Day } 0 \text { and } \\
\text { ovulating }(\%)\end{array}$ & $16 \cdot 7$ & $0 \cdot 0$ & - & - \\
\hline Onset of oestrus (h) & $42 \cdot 6 \pm 4 \cdot 6$ & $50 \cdot 6 \pm 4 \cdot 4$ & $45 \cdot 1 \pm 5 \cdot 8$ & $47 \cdot 7 \pm 3 \cdot 0$ \\
\hline Ovulation rate & $1 \cdot 8 \pm 0 \cdot 3(6)$ & $1 \cdot 3 \pm 0.2(6)$ & $2 \cdot 0 \pm 0 \cdot 4(4)$ & $1 \cdot 2 \pm 0 \cdot 2(6)$ \\
\hline
\end{tabular}

Values are mean \pm standard error for the no. of ewes indicated in parentheses.

${ }^{a, b}$ Means within a treatment with different letters differ significantly $(P<0.05)$.

observed for the time to onset of oestrus. One B-crossed ewe did not ovulate and the ovulation rate per ewe differed $(P<0.07)$ between genetic groups.

No differences were found between groups in which the Fl follicle was left intact (Treatment 1) or destroyed (Treatment 2) in number of follicles $\geq 4 \mathrm{~mm}$ and 3-4 mm at Day 4 , ovulation rate and onset of oestrus.

In the control group (Treatment 3, data not shown), no follicle marked at Day 0 ovulated in B-crossed ewes 4 days after marking while $2 \mathrm{~F} 2$ and $1 \mathrm{~F} 3$ follicles ovulated in $\mathrm{S}$ ewes. There was no difference in the mean time to onset of oestrus between the two groups $(50.7$ and $47.1 \mathrm{~h}$ for B-crossed and S ewes) and only one B-crossed ewe did not show oestrus. Two (2) B-crossed ewes did not ovulate and ovulation rate per ewe ovulating was 1.5 for B-crossed and 1.0 for $\mathrm{S}$ ewes $(P<0.06)$.

\section{Discussion}

The higher ovulation rate in Booroola $\times$ Finnish Landrace and Booroola $\times$ Suffolk ewes was not related to increased macroscopic follicular population, which is consistent with other reports on Booroola Merino sheep (Driancourt et al., 1985a, c; McNatty et al., 1986). The absence of correlation between ovulation rate and the total follicular population was also observed many times both in between- and within-breed comparison (Romanov vs Ile-de-France: Driancourt et al., 1986; Finn selected for high $v$ s low ovulation rate: Driancourt et al., 1990).

It was not expected that almost every $F 1$ follicle left intact on the ovary after destruction of all other visible follicles (Group 1, Exp. 1) would ovulate since it has been demonstrated that a great proportion (higher than $50 \%$ ) of large follicles present at different times of the oestrous cycle are atretic (Brand \& DeJong, 1973; Carson et al., 1979; Dott et al., 1979). It is likely that a relatively large proportion of F1 follicles left in Group 1 (Exp. 1) would have been atretic at Day 0. Two hypotheses are postulated to explain the persistence of the only follicle remaining in the ovaries: $(1)$ 
diminution of intraovarian inhibitors of follicular growth which are abundant in small follicles (diZerega et al., 1987; Driancourt \& Fry, 1988) and (2) rescue of follicles from atresia. The potential effect of follicular rescue from atresia by PMSG observed in different species (mice: Peters et al., 1975; sheep: Hay \& Moor, 1977; cattle: Monniaux et al., 1984) highlights the possible role of FSH in rescue and/or prevention of atresia. This hypothetical effect of FSH could have been enhanced by the absence of other follicles, thereby increasing the amount of FSH available for the F1 follicle. However, since recovery from atresia could not be demonstrated in vivo (sheep: Hay et al., 1979; rat: Hirshfield, 1989), the diminution of intraovarian inhibitors seems to be the more likely explanation.

The drastic destruction of all visible follicles at sponge removal did not allow follicles coming from the $<0.5 \mathrm{~mm}$ pool to be recruited in 2 days in Group 1 or in Group 2 (Exp. 1). This finding is in agreement with those of several other workers (Driancourt \& Cahill, 1984; Tsonis et al., 1984) who reported that recruitment of follicles destined to ovulate is made from follicles $\geq 2 \mathrm{~mm}$ at luteolysis. Follicles of smaller size do not have the ability to mature and ovulate during the normal period of time between luteolysis and ovulation. In the present experiment, the first ovulation in ewes of Group 2, in which all visible follicles were destroyed (Exp. 1), occurred only about 16 days following treatment. Tsonis et al. (1984) destroyed follices of $\geq 2 \mathrm{~mm}$ and delayed ovulation by $24 \mathrm{~h}$. The time taken by a follicle $<0.5 \mathrm{~mm}$ to grow to preovulatory size was certainly too long to allow ovulation to occur quickly after the presumed $\mathrm{LH}$ surge of the first oestrus. Even if all follicles had been destroyed, the concentrations of oestrogen might have been high enough to allow oestrous behaviour and probably also to induce the LH surge. However, it is not known why ovulation was delayed for so long following our treatment. Previous experiments by Dufour et al. (1971) showed that, after destruction of all visible follicles on Day 8 of the oestrous cycle, 5 of 8 ewes showed oestrus in a mean time of 3.6 days after treatment, but none of the ewes had ovulated by Day 4 following treatment, an observation consistent with our results.

The results on follicular dynamics confirm that selection of ovulatory follicles can take place both before and after luteolysis (Smeaton \& Robertson, 1971; Findlay \& Cumming, 1977) and that ovulatory follicles can be recruited from a wide range of sizes (Tsonis et al., 1984). However, for prolific genotypes of sheep in this work, selection of ovulatory follicles appeared to take place throughout the follicular phase as previously reported for Booroola ewes by Driancourt et al. (1985a) and could occur as late as several hours after onset of oestrus. In Exp. 1, some follicles coming from the $3-4 \mathrm{~mm}$ pool at Day 2 eventually ovulated, which is consistent with the fact that follicles attained maturity at smaller size in Booroola ewes (Driancourt et al., 1985a; McNatty et al., 1985). This characteristic would therefore allow a higher turn-over of the follicles without any alteration of the ovulation rate. A large proportion of follicles marked at luteolysis (Day 0 ) became atretic by ovulation time and were replaced by smaller follicles starting to grow later in the follicular phase. Rate of atresia between Days 0 and 2 among marked follicles was lower in Finn than in B-crossed ewes, as previously shown by Driancourt et al. (1986). However, although more large marked follicles increased in size, the proportion that reached ovulation was similar to that observed for B-crossed females. In Suffolk ewes, selection was almost already made at the beginning of the follicular phase since a high proportion of largest follicles (F1 and F2) marked at Day 0 ovulated (Exp. 1). This early follicularphase recruitment pattern has also been observed in other non-prolific sheep (DLS: Bhérer et al., 1976; Merino: Driancourt et al., 1985a).

The diameter of the largest follicle observed at different times was higher in Suffolk ewes, which confirms other reports that maximum diameter attained by a preovulatory follicle is higher in non-prolific breeds (Webb \& Gauld, 1985; Driancourt et al., 1986). The smaller preovulatory follicular size observed in BFL, BS and FL seems to be a common feature of prolific breeds (Booroola: Scaramuzzi \& Radford, 1983; Finn: Webb \& Gauld, 1985; Romanov: Driancourt et al., 1986). However, since a higher ovulation rate $_{D}$ is $_{n}$ related $_{\mathrm{r}}$ to smaller $_{\mathrm{i}}$ preovdatory $_{2}$ follicle $_{1}$ size $_{52 \mathrm{AM}}$ 
it becomes difficult to dissociate the effect of breed from the effect of ovulation number. Growth rates between Days 0 and 2 for growing F1, F2 or F3 follicles were consistent with other results (Turnbull et al., 1977; Driancourt et al., 1988) and were the same for prolific and non-prolific genotypes as also observed by Driancourt et al. (1986). No follicle maintaining a steady size between Days 0 and 2 ovulated, which is different from what has been reported by Driancourt $e t$ al. (1985a) for Booroola ewes.

Prolific ewes in control groups (Group 3 and Treatment 3) in the 2 experiments exhibited a lower ovulation rate compared to those registered for the first oestrus of the breeding season. Although follicular development was not affected by ink-marking, as observed by the presence of numerous presumably preovulatory follicles in the four genotypes at Day 2 (Group 3, Exp. 1), it seems that ovulation itself was altered in polyovulatory ewes. It appears that ewes shedding several ova were more affected by the surgery (anaesthesia, ink-marking) than were non-prolific ewes. In Exp. 2, performed near the end of the breeding season, the reduction in ovulation rate in prolific and non-prolific ewes suggests that the time of the season may constitute another possible explanation for the decrease in ovulation rate observed in that experiment (Wheeler \& Land, 1977). An association between the end of the breeding season and the reduction of ovarian activity has been reported by McNatty et al. (1984). Overall, then, both ink-marking and timing of Exp. 2 may have somewhat depressed ovulation of polyovulatory ewes. Nevertheless, significant differences in ovulation rate between prolific and non-prolific females were always obtained.

The main finding of this report is that dominance (Baird, 1983; Driancourt et al., 1985b) was not demonstrated in ewes of prolific or non-prolific genotypes: in Exp. 2, the largest follicle did not have a negative effect on growth of smaller follicles. It is likely that, if dominance of the F1 follicle was present, growth of $1-3 \mathrm{~mm}$ follicles that were left in the ovaries would have been inhibited during the 4 days between observations, and that the F1 follicle would have continued its growth to ovulation. On the contrary, the results of Exp. 2 showed that: (1) the number of 3-4 mm follicles was similar at Day 4 in ewes with the F1 follicle left intact (Treatment 1) or destroyed (Treatment 2); (2) follicles $\geq 4 \mathrm{~mm}$ were more numerous at Day 4 in ewes with the F1 follicle intact; (3) a higher proportion of F1 follicles regressed between Days 0 and 4 in Treatment 1; (4) the F1 follicles left intact at Day 0 (Treatment 1) were replaced by an F2 follicle at Day 4 of size similar to that of the original F1 follicle. Therefore, the presence or absence of FI follicles appears to have no effect on the number of follicles of $\geq 3 \mathrm{~mm}$ at Day 4 . Our observations are consistent with those of Smith et al. (1984) who showed that, at 7 days after unilateral ovariectomy, the increase in ovarian weight and follicular fluid weight observed was similar in ewe lambs in which the ovary having the largest follicle(s) was removed compared with the group in which it was retained. No effect of the largest follicle could therefore be demonstrated. In contrast, comparison of Group 1 and Treatment 1 (Exp. 1 and 2) strongly suggests that smaller follicles $(1-3 \mathrm{~mm})$ remaining in the ovaries have a negative effect on the maintenance of the largest follicle: in the absence of small sized follicles (Group 1, Exp. 1), the F1 follicle attained ovulation and avoided atresia, but when small follicles were present (Treatment 1, Exp. 2) a large proportion of $F 1$ follicles regressed $(92 \%)$. The greater size increase of $F 1$ follicles in Group 1 ewes compared to Group 3 (Exp. 1) supports the hypothesis that small follicles inhibit growth of larger ones.

In conclusion, the high ovulation rate of Booroola crossed ewes was not due to a higher number of follicles available at the time of recruitment. Rather, it involved extended follicular-phase recruitment and smaller preovulatory follicle diameters. No effect of the largest follicle on growth of smaller ones was observed. On the contrary, it seems likely that follicles of 1-3 mm induce atresia of larger ones.

We thank Dr Marc-Antoine Driancourt for helpful discussions; Jean-Pierre Huot, Alcide Cormier and Jean-Pierre Girard for animal care at the experimental station of Laval University. This research was supported by grants from Agriculture Quebec (CORPAQ) and Agriculture Canada. 


\section{References}

Baird, D.T. (1983) Factors regulating the growth of the preovulatory follicle in the sheep and human. $J$. Reprod. Fert. 69, 343-352.

Baird, D.T. (1987) A model for follicular selection and ovulation: lessons from superovulation. J. Steroid Biochem. 27, 15-23.

Bhérer, J., Dufour, J. \& Matton, P. (1976) Destinée des deux plus gros follicules des ovaires de brebis à la suite de la destruction du plus gros follicule et/ou de l'enlèvement du corps jaune à deux moments $\mathrm{du}$ cycle. Can. J. Physiol. Pharmacol. 54, 7-11.

Brand, A. \& DeJong, W.H.R. (1973) Qualitative and quantitative micromorphological investigations of the tertiary follicle population during the oestrous cycle in sheep. J. Reprod. Fert. 33, 431-439.

Cahill, L.P., Driancourt, M.A., Chamley, W.A. \& Findlay, J.K. (1985) Role of intrafollicular regulations and FSH in growth and development of large antral follicles in sheep. J. Reprod. Fert. 75, 599-607.

Carson, R.S., Findlay, J.K., Burger, H.G. \& Trounson, A.O. (1979) Gonadotropin receptors of the ovine ovarian follicle during follicular growth and atresia. Biol. Reprod. 21, 75-87.

Castonguay, F., Minvielle, F. \& Dufour, J.J. (1990) Reproductive performance of Booroola $\times$ Finnish Landrace and Booroola $\times$ Suffolk ewe lambs, heterozygous for the $\mathrm{F}$ gene, and growth traits of their three-way cross lambs. Can. J. Anim. Sci. (in press).

diZerega, G.S. \& Hodgen, G.D. (1980) The primate ovarian cycle: suppression of human menopausal gonadotropin induced follicular growth in the presence of the dominant follicle. J. clin. Endocr. Metab. 50, 819-825.

diZerega, G.S., Tonetta, S.A. \& Westhof, G. (1987) A postulated role for naturally occurring aromatase inhibitors in follicle selection. J. Steroid Biochem. 27, $375-383$.

Dorrington, J.H., Bendell, J.J., Chuma, A. \& Lobb, D.K. (1987) Actions of growth factors in the follicle. $J$. Steroid Biochem. 27, 405-411.

Dott, H.M., Hay, M.F., Cran, D.G. \& Moor, R.M. (1979) Effect of exogenous gonadotrophin (PMSG) on the antral follicle population in the sheep. $J$. Reprod. Fert. 56, 683-689.

Driancourt, M.A. (1987) Follicular dynamics and intraovarian control of follicular development in the ewe. In Follicular Growth and Ovulation Rate in Farm Animals, pp. 87-105. Eds J. F. Roche \& D. O'Callagnan. Martinus Nijhoff, Dordrecht.

Driancourt, M.A. \& Cahill, L.P. (1984) Preovulatory follicular events in sheep. $J$. Reprod. Fert. 71, 205-211.

Driancourt, M.A. \& Fry, R.C. (1988) Differentiation of ovulatory follicles in sheep. J. Anim. Sci. 66 (Suppl. 2), 55-66.

Driancourt, M.A., Cahill, L.P. \& Bindon, B.M. (1985a) Ovarian follicular populations and preovulatory enlargement in Booroola and control Merino ewes. $J$. Reprod. Fert. 73, 93-107.

Driancourt, M.A., Gibson, W.R. \& Cahill, L.P. (1985b) Follicular dynamics throughout the oestrous cycle in sheep. A review. Reprod. Nutr. Dévelop. 25, 1-15.
Driancourt, M.A., Yego, Y., Cahill, L.P. \& Bindon, B.M. $(1985 \mathrm{c})$ Follicle population dynamics in sheep with different ovulation rate. Livest. Prod. Sci. 13, 21-33.

Driancourt, M.A., Gauld, I.K., Terqui, M. \& Webb, R. (1986) Variations in patterns of follicle development in prolific breeds of sheep. J. Reprod. Fert. 78, 565-575.

Driancourt, M.A., Philipon, P., Locatelli, A., Jacques, E. \& Webb, R. (1988) Are differences in FSH concentrations involved in the control of ovulation rate in Romanov and Ile-de-France ewes. J. Reprod. Fert. 83, 509-516.

Driancourt, M.A., Castonguay, F., Bindon, B.M., Piper, L.R., Quirke, J.F. \& Hanrahan, J.P. (1990) Ovarian follicular dynamics in lines of sheep (Finn, Merinos) selected on ovulation rate. J. Anim. Sci. (in press).

Dufour, J., Ginther, O.J. \& Casida, L.E. (1971) Corpus luteum action on ovarian follicular development after destruction of macroscopically visible follicles in ewes. Proc. Soc. exp. Biol. Med. 138, 475-478.

Dufour, J.J., Whitmore, H.L., Ginther, O.J. \& Casida, L.E. (1972) Identification of the ovulating follicle by its size on different days of the estrous cycle in heifers. J. Anim. Sci. 34, 85-87.

Dufour, J., Cahill, L.P. \& Mauléon, P. (1979) Short- and long-term effects of hypophysectomy and unilateral ovariectomy on ovarian follicular populations in sheep. J. Reprod. Fert. 57, 30I-309.

Findlay, J.K. \& Cumming, I.A. (1977) The effect of unilateral ovariectomy on plasma gonadotropin levels, estrus and ovulation rate in sheep. Biol. Reprod. 17, 178-183.

Fry, R.C., Clarke, I.J., Cummins, J.T., Bindon, B.M., Piper, L.R. \& Cahill, L.P. (1988) Induction of ovulation in chronically hypophysectomized Booroola ewes. J. Reprod. Fert. 82, 711-715.

Hay, M.F. \& Moor, R.M. (1977) Changes in the Graafian follicle population during the follicular phase of the oestrous cycle. In Control of Ovulation, pp. 177-196. Eds D. B. Crighton, N. B. Haynes, G. R. Foxcroft \& G. E. Lamming. Butterworth, London.

Hay, M.F., Moor, R.M., Cran, D.G. \& Dott, H.M. (1979) Regeneration of atretic sheep ovarian follicles in vitro. J. Reprod. Fert. 55, 195-207.

Hirshfield, A.N. (1989) Rescue of atretic follicles in vitro and in vivo. Biol. Reprod. 40, 181-190.

Hodgen, G.D. (1982) The dominant ovarian follicle. Fert. Steril. 38, 281-300.

Matton, P., Adelakoun, V., Couture, Y. \& Dufour, J.J. (1981) Growth and replacement of the bovine ovarian follicles during the estrous cycle. J. Anim. Sci. 52, 813-820.

McNatty, K.P., Hudson, N.L., Henderson, K.M., Lun, S., Heath, D.A., Gibb, M., Ball, K., McDiarmid, J.M. \& Thurley, D.C. (1984) Changes in gonadotrophin secretion and ovarian antral follicular activity in seasonally breeding sheep throughout the year. $J$. Reprod. Fert. 70, 309-321.

McNatty, K.P., Henderson, K.M., Lun, S., Heath, D.A., Ball, K., Hudson, N.L., Fannin, J., Gibb, M., Kieboom, L.E. \& Smith, P. (1985) Ovarian activity in Down Booroola $_{1} \times_{1}$ Romney ewes which have a $_{2}$ major gene $_{2 \mathrm{AM}}$ 
influencing their ovulation rate. J. Reprod. Fert. 73, $109-120$.

MeNatty, K.P., Lun, S., Heath, D.A., Ball, K., Smith, P., Hudson, N.L., McDiarmid, J., Gibb, M. \& Henderson, K.M. (1986) Differences in ovarian activity between Booroola $\times$ Merino ewes which were homozygous, heterozygous and non-carriers of a major gene influencing their ovulation rate. J. Reprod. Fert. 77, 193-205.

McNeilly, A.S., Jonassen, J.A. \& Fraser, H.M. (1986) Suppression of follicular development after chronic LHRH immunoneutralization in the ewe. $J$. Reprod. Fert. 76, 481-490.

Monniaux, D., Mariana, J.C. \& Gibson, W.R. (1984) Action of PMSG on follicular populations in the heifer. J. Reprod. Fert. 70, 243-253.

Peters, H., Byskov, A.G., Himelstein-Braw, R. \& Faber, M. (1975) Follicular growth: the basic event in the mouse and human ovary. J. Reprod. Fert. 45, 559-566.

SAS Institute (1985) SAS User's Guide. SAS Institute Inc., Cary, North Carolina, USA.

Scaramuzzi, R.J. \& Radford, H.M. (1983) Factors regulating ovulation rate in the ewe. $J$. Reprod. Fert. 69 , 353-367.

Shaw, G., Jorgensen, G.I., Tweedale, R., Tennison, M. \& Waters, M.J. (1985) Effect of epidermal growth factor on reproductive function of ewes. J. Endocr. 107, $429-436$.

Smeaton, T.C. \& Robertson, H.A. (1971) Studies on the growth and atresia of Graafian follicles in the ovary of the sheep. J. Reprod. Fert. 25, 243-252.
Smith, M.F., Agudo, L.Sp., Schanbacher, B.D. \& Hruska, R.L. (1984) Follicle stimulating hormone secretion and compensatory ovarian hypertrophy in prepubertal ewes. Theriogenology 21, 969-979.

Staigmiller, R.B. \& England, B.G. (1982) Folliculogenesis in the bovine. Theriogenology 17, 43-52.

Tsonis, C.G., Cahill, L.P., Carson, R.S. \& Findlay, J.K. (1984) Identification at the onset of luteolysis of follicles capable of ovulation in the ewe. J. Reprod. Fert. 70, 609-614.

Turnbull, K.E., Braden, A.W.H. \& Mattner, P.E. (1977) The pattern of follicular growth and atresia in the ovine ovary. Aust. J. biol. Sci. 30, 229-241.

Webb, R. \& Gauld, I.K. (1985) Folliculogenesis in sheep: control of ovulation rate. In Genetics of Reproduction in Sheep, pp. 261-274. Eds R. B. Land \& D. W. Robinson. Butterworth, London.

Wheeler, A.G. \& Land, R.B. (1977) Seasonal variation in oestrus and ovarian activity of Finnish Landrace, Tasmanian Merino and Scottish Blackface ewes. Anim. Prod. 24, 363-376.

Ying, S.H., Becker, A., Ling, N., Veno, N. \& Guillemin, R. (1986) Inhibin and beta type transforming growth factor have opposite modulating effects on the follicle stimulating hormone induced aromatase activity of cultured rat granulosa cells. Biochem. Biophys. Res. Commun. 136, 969-975. 